\title{
REFERÁTUMKÉSZÍTÉS: EGY ELFELEJTETT KÉSZSÉGEGYÜTTES?
}

\section{Szerző:}

Koltay Tibor (PhD, habil.)

Eszterházy Károly Katolikus Egyetem

Nyíregyházi Egyetem

A szerző e-mail címe:

koltay.tibor@uni-eszterhazy.hu

\section{Lektorok:}

\author{
Varga Katalin (PhD, habil.) \\ Pécsi Tudományegyetem
}

Tanyiné Kocsis Anikó (PhD)

Nyíregyházi Egyetem

...és további két anonim lektor

\begin{abstract}
Absztrakt
Az eredményes referátumkészítéshez olyan készségek együttesét kell ismernünk, amelyek már régóta velünk vannak, viszont sokan nincsenek tisztában ezek fontosságával. Ugyanakkor tudjuk, hogy leggyakrabban az autoreferátum múfajával találkozunk. Ezeket szerzői referátumnak, absztraktnak, vagy kivonatnak nevezett írásművet többnyire a forrásszövegként szolgáló tudományos folyóiratcikkek szerzői írják, de vannak olyan referátumok is, amelyek hivatásos referátumkésztők munkái. A modern technológiák viszont a számos, a referáláshoz köthető új múfajt és eszköz megjelenését segítették elő. A referátumok összes alfaja jó eszközt jelent az információs túlterhelés csökkentésére.
\end{abstract}

Kulcsszavak: referátumkészítés, információs műveltség, információs túlterhelés

Diszciplína: nyelvtudomány, információtudomány, kommunikáció- és médiatudomány, pedagógia

\section{Abstract}

ABSTRACTING: A FORGOTTEN SET OF SKILLS?

To be efficient abstractors, we need to acquire a set of skills that have been with us for a long time, but many people are not aware of their significance. At the same time, we know that the most often encountered genre is the author abstract, written mostly by the authors of scientific journal articles that serve as source text, but there are 
professional abstractors, as well. Modern technologies, on the other hand, have fostered the emergence of many new genres and tools for abstracting. All types of abstract are useful tools for reducing information overload.

Keywords: abstracting, information literacy, information overload

Disciplines: linguistics, information science, communication and media science, pedagogy

Koltay Tibor (2021): Referátumkészítés: egy elfelejtett készségegyüttes? OxIPO interdiszciplináris tudományos folyóirat, 2021/3, 9-16. doi: 10.35405/OXIPO.2021.3.9

A referálás (referátumkészítés) referátumok létrehozása (megírása). Ennek a tevékenységnek a során egy, az írott (természetes nyelvi) forrásszöveg nyelvével azonos vagy attól eltérő nyelvű - szintén írott, természetes nyelvi - célszöveg jön létre. Vannak altípusai is, azonban ezek közös vonása, hogy a forrásszöveg valamilyen szempontból legfontosabbnak tartott tartalmát annál rövidebb terjedelemben reprezentálják. Segítségükkel eldönthető, hogy el kell-e olvasnunk az adott cikk teljes szövegét (Koltay, 2019). Bár ebben az írásban is találkoztatunk a témát tárgyaló, viszonylag friss szakirodalommal, a referátumok és a referátumkészítés mintha a maga Csipkerózsika-álmát aludná, miközben ennek az alapvetően interdiszciplináris múfajcsoportnak új készségei jelentek meg. Ezt még súlyosbítja, hogy ezen a területen nincs egységes terminológia. Ugyanakkor az új technológiák térnyerésének köszönhetően, a referáláshoz kötődő, új eszközök és újabb műfajok jelentek meg.

\section{Fogalmak és kontextusok}

Ha a referátum szerzője azonos a forrásszöveg szerzőjével, autoreferátumnak (szerzői referátumnak, absztraktnak, kivonatnak) nevezzük. A szerző személyében meglevő különbségtől eltekintve a referátum és autoreferátum közeli rokonai egymásnak, ezért a következőkben többnyire mindkettőre a referátum szót fogjuk használni. A referátum köré csoportosuló műfajcsoport egészét a kivonat szóval és annak származékaival is illethetjük (Márta, 2004).

A téma angol nyelvű terminusait azért érdemes megemlítenünk, mert az abstract szó rokona az abstracting, amely az absztrakció hétköznapi használatában az elvonatkoztatást, azaz a lényeges és lé- 
nyegtelen tulajdonságok elválasztását, a lényeges tulajdonságok kiemelését és a lényegtelen tulajdonságok figyelmen kívül hagyását jelenti.

Ehhez a gondolkodásmódhoz kapcsolódóan a referátum szó az írásbeli kommunikáció olyan múfaját takarja, amelyet túlnyomórészt, de nem kizárólagosan intellektuális erőfeszítés útján jön létre. Ennek a közelebbi kontextusában egyaránt ott van az elvonatkoztatás (mint tevékenység) és a különféle célszövegek létrehozásának igénye és folyamata.

A referálás szó legtöbbször a szöveges összefoglalók (referátumok) készítésével (megírásával) kapcsolatos tevékenységeket takarja. A referátumkészítés alapjául szolgáló technikák lényege az, hogy információk szelektív összefoglalása útján egy, már létező (szakmai vagy tudományos) forrásszöveg (általában folyóiratcikk) legfontosabb tartalmát egy olyan önálló célszövegben jelenítjük meg, amely ezt az információt rövidített formában, tartalmazza.

Annak eldöntése, hogy a forrásszövegnek mi a legfontosabb tartalma a referálás egyik fő szakasza. Használható referátumot akkor tudunk írni, ha csak a forrásszövegben található, fontosnak vagy jelentősnek ítélt (válogatott) információkat visszük át a célszövegbe. Az e követelménynek való megfelelés érdekében a referálás folyamata megkönnyíti az ismeretszerzést azáltal, hogy a specifikustól az általános felé halad, kiküszöbölve a vélet- lenszerűt és megőrizve a lényegest (Pinto, 1995).

A referátumok tehát szelektív módon tükrözik a tudományos és szakmai írások tartalmát, attól függően, hogy a szerző és a referátum készítője mit tart fontosnak, hogy megkönnyítsék annak megítélését, hogy egy adott információs igény szempontjából minek van relevanciája. A tudományos cikkek tartalmát tükröző referátumok ezért az ezekben található információk és érvelés komplexitásának csak egy részét adják vissza (Atanassova, Bertin és Larivière, 2016).

Ennek megfelelően a referálás nem olyan egyszerű feladat, amelyet bárki elvégezhet előzetes (formális vagy informális) képzés nélkül, bár a forrásszövegben megjelenő szakmai, tudományos tartalom ismeretében a gyakorlat során elsajátíthatók az ehhez szükséges készségek (Pinto, Fernández-Ramos és Doucet, 2008a). Általánosságban elmondható, hogy a referálás intelligenciát, képzelőerőt, önállóságot és a szervezett munkavégzés képességét igényel (Endres-Niggemeyer, 1998). Szigorúságra, pontosságra, és következetességre is szükség van (Pinto, Fernández-Ramos és Doucet, 2008b).

A tudományos folyóiratokban való publikáláskor a kutatóknak szerzői összefoglalókat (autoreferátumokat) kell összeállítaniuk, amelyek kísérik a dolgozataikat. Ebben az esetben a referátumokat jellemző módon a forrásszövegek szerzői írják meg. Sok referátumot azonban valamely szervezet által megbízott referálók készí- 
tenek el. Ehhez meg kell ismerniük a forrásszöveg szakmai (tudományos) tartalmát, ami - a már említett olvasás készségek mellett - az érvek világos megfogalmazását is megkövetelik (Koltay, 2010).

A hivatásos (többnyire részmunkaidőben dolgozó) referátumkésztőknek tisztában kell lenniük közvetítő szerepükkel, mivel retorikai, funkcionális és szemantikai természetű döntéseket kell hozniuk. A referálás speciális kontextusokban bontakozik ki, egy sor kontextuális valószínüségre figyelve, amelyek meghatározzák az eredeti szöveg tartalmának szintjét és azt az adott diskurzusközösség érzékelt elvárásaihoz igazítják, ami az informatív és kommunikatív viselkedés bizonyos mintáinak alkalmazását igényli (Izquierdo Alonso és Moreno Fernández, 2010). Ezek közé tartoznak a referálásban (is) felhasználásra kerülő, speciális olvasási technikák. Ezek egyike a tudományos kutatás céljára végzett olvasás, amely egyszerre jelenti a szöveg elmélyült, kritikai tanulmányozását és azt, hogy az ismert tényeket ismert módon tárgyaló szövegrészeket nem olvassuk el, hanem csak áttekintjük. Ez tehát válogató olvasás, amelynek eredményeként a kiválogatott szövegrészeket nem memorizáljuk, hanem kijegyzeteljük (Koltay, 2003).

A referátumok értékelésének legfontosabb szempontjai a következők:

- Elegendő, a forrásszövegből vett, fontos információt tartalmaz-e a referátum?
- A referáló kihagyta-e a felesleges részleteket?

- Mennyire jól van megfogalmazva a referátum?

\section{Félprofesszionális}

\section{és laikus összefoglalók}

A szerzők és a referálók által készített referátumok mellett létezik a félprofesszionális szintű összegzés, amely viszonylag rendszeresen végezhetünk, de nem tekinthető főtevékenységnek vagy kizárólagos foglalkozásnak.

$\mathrm{Az}$ autoreferátumok írása a professzionális és a félprofesszionális referálás határán mozog. A referálási technikák elsajátítása a cikkek szerzői számára is hasznos lenne, amikor autoreferátumokat írnak, különös tekintettel arra, hogy minőségük gyakran nem megfelelő, ezért számos tudományos folyóirat megköveteli a strukturált referátumok elkészítését. Ezek esetében ugyanis elvárás, hogy a szükséges információk előre rögzített (és tipográfiailag kiemelt) címszavak („fejezetcímek”) alá legyenek rendezve (Koltay 2010).

Ezen kívül félprofesszionális referálás az is, amikor

- A hallgatók jegyzeteket készítenek az előadásokon,

- Újságírók sajtótájékoztatók eredményeirôl számolnak be,

- A kutatók konferencia-összefoglalókat írnak (Endres-Niggemeyer, 1998). 
Ez utóbbiakat gyakran az absztraket szóval nevezzük meg, feltehetőleg azért is, mert különböznek a referátumok többi típusától, mivel esetükben nem egy, már meglévő szöveget alakítunk át tömörebb formára, hanem egy teljesen új szöveg készül, amely előrevetíti, hogy az adott kutató miről kíván beszélni egy adott konferencián.

A laikus (hétköznapi, alkalmi) összefoglalók készítésére példa egy nemrég látott film vagy televíziós műsor lényegének elmesélése. Az ilyen tevékenységek nem igényelnek különösebb erőfeszítést, előzetes képzést vagy különleges készségeket, mert olyan tartalomra épülnek, amelyet valaki saját emlékezetéből külső forrás felhasználása nélkül hív elő.

\section{A referátumok egyéb típusai}

Bár a számítógépes nyelvészet kezdete óta igény volt referátumok automatikus létrehozására (Orasan, 2019) és ezt a tevékenységkört napjainkban is folyamatosan kutatják. A referátumkészítés azonban továbbra is főként intellektuális (kézi) munka maradt (King et al, 2018).

A tudományos kutatóknak szánt közösségi média egyre nagyobb mértékű jelenlétével együtt (Koltay 2017a) a referátumok - bár szokatlan formában - újra felbukkannak. A Kudos (lásd: Net1) célközönségének egy részét a laikusok képezik, mivel a kutatóknak és a szakembereknek szánt autoreferátumok „érthe- tőbb" kivonatait közlik. Ilyen módon a Kudos által kért referátumok a laikus összefoglaló kategóriába is beillenek. Ugyanakkor - mivel alapjukat az autoreferátumok képezik, és ezeket köztudomásúan maguk a kutatók írják - félprofesszionális tevékenység nyomán jönnek létre.

A szöveges referátumok mellett létezik strukturált vagy strukturálatlan adatok számítógépes összefoglalása is, amely a gépi tanulás, a statisztikai elemzések, a szemantika és a természetes nyelvi feldolgozás felhasználásával történik meg (Ahmed, 2019).

Felismerve, hogy egy tanulmány főbb megállapításainak összefoglalása vizuális formában is elvégezhető, megjelent az autoreferátumok két új típusa, a grafikus és a videó-referátum.

A grafikus referátumok szerzői - hasonlóan ahhoz, ahogyan előadásokon és prezentációkban osztják meg kutatásukat - olyan diákat használnak, amelyek a cikk fő üzenetét és a cikkre vonatkozó metaadatokat közvetítő képeket tartalmazzák, könnyen megjegyezhető formában. A grafikus referátumokat leggyakrabban a szerzők készítik, de egyes folyóiratok technikai segítséget nyújtanak a létrehozásukhoz vagy szerkesztésükhöz (Pittman, G. és, Pratta, S. 2021). A videó-referátumok ugyanakkor abban hasonlítanak a szöveges referátumokra, hogy jellemzően a tanulmány hátterét, a módszertant, az eredményeket és a lehetséges következményeket közlik (Reupert, 2017). 


\section{A referálás}

\section{és az információs túlterhelés}

A szöveges, grafikus és videós referátumok nemcsak azért lehetnek hasznosak, mert lehetővé teszik a releváns információk azonosítását és összefoglalását, hanem azért is, mert képesek szerepet játszani az információs túlterhelés „megszelídítésében”, (Koltay, 2017b). Az információs túlterhelést úgy definiálhatjuk, mint objektív és szubjektív nehézségek összességét, amelyet a rendelkezésre álló információk mennyisége és összetettsége, valamint az ilyen helyzetek kezelésére való képtelenségünk okoz (Koltay, 2020).

A referálás célja az időmegtakarítás is, hiszen képes az informáló erővel rendelkező tartalmak azonosítására, ideértve az információkat és az adatokat is. A referátumkészítésnek arra kell épülnie, hogy információ bizonyos, kiválasztott részeinek fontosságára összpontosítunk az információs műveltség lényeges alkotóelemét jelentô kritikai gondolkodás alkalmazásával (Koltay 2009). Ha pedig elfogadjuk, hogy az adatműveltség az a képesség, hogy tudjuk, miként válasszuk ki és szintetizáljuk az adatokat és hogyan kombináljuk azokat más információforrásokkal (Calzada Prado és Marzal, 2013), akkor azt mondhatjuk, hogy a referáláshoz szükséges készségek, az adatműveltségnek is részei.

Az üzenetek tömörítésének szintje alacsonyabb lehet a félprofesszionális és a laikus összefoglalók készítése esetében, azonban nem kétséges, hogy az eltérő motivációk ellenére is értékes időt takarítanak meg.

Az referátumok a személyes információkezelés (Personal Information Management, PIM) eszközeiként is működhetnek, amely az információs túlterhelés tüneteinek enyhítésére irányul. A PIM olyan tevékenység, amelynek során az egyének személyes információs elemeket tárolnak, hogy később visszakereshessék azokat (Bergman, 2013). Saját, személyes sémájukat alkalmazva az egyének a hozzáférhető információk halmazából személyes információkat hozhatnak létre és szükség esetén felhasználhatják azokat (Franganillo, 2009). Ma már azt is látjuk, hogy mindez az adatokra is igaz.

\section{Irodalom}

Ahmed, M. (2019). Data summarization: a survey. Knowledge and Information Systems, 58, 2, 249-273. DOI 10.1007/s10115-018-1183-0

Atanassova, I. Bertin, M. és Larivière, V. (2016). On the composition of scientific abstracts. Journal of Documentation, 72, 4, 636-647. DOI 10.1108/JDOC-09-2015-0111

Bergman, O. (2013). Variables for personal information management research. Aslib Proceedings, 65, 5, 464483. DOI 10.1108/AP-04-2013-0032 Calzada Prado, J. C. és Marzal, M. A. (2013). Incorporating data literacy into information literacy programs: Core 
competencies and contents. Libri, 63, 2, 123-134. DOI 10.1515/libri-20130010

Franganillo, J. (2009). Gestión de información personal: elementos, actividades e integración. Profesional de la Información, 18, 4, 399-406. DOI 10.3145/epi.2009.jul.06

Izquierdo Alonso, M. és Moreno Fernández, L. M. (2010). Perspectives of studies on document abstracting: Towards an integrated view of models and theoretical approaches. Journal of Documentation. 66, 4, 563-584. DOI 10.1108/00220411011052957

King, S., Boyedoe, H., Chacon, A., Hall, M., Krizansky, M., O’Bryant, K., ... és Alemneh, D. (2018). Revisiting Indexing and Abstracting in the Digital Era.

(Letöltés: 2021.06.10.) Web:

https://digital.library.unt.edu/ark:/ 67 531/metadc1164546/

Koltay T. (2003). A referálás elmélete és gyakorlata. Budapest: Országos Széchényi Könyvtár.

Koltay, T. (2009). Abstracting: information literacy on a professional level. Journal of Documentation, 65, 5, 841-855. DOI 10.1108/00220410910983146

Koltay, T. (2010). Abstracts and Abstracting: A genre and set of skills for the twenty-first century. Chandos, Oxford.

Koltay T. (2017a). Egy „örökzöld téma": az információs túlterhelés. Információs Társadalom, 17, 3, 39-54. DOI 10.22503/inftars.XVII.2017.3.2
Koltay T. (2017b). A kutatóknak szánt közösségi médiáról. Magyar Tudomány, 178, 10, 1303-1310. DOI 10.1556/2065.178.2017.10.14

Koltay T. (2019). Fordítás-e a referálás? Pro és kontra érvek. Fordítástudomány, 21, 1, 62-75.

Koltay, T. (2020). Information Overload. In Encyclopedia of Organizational Knowledge, Administration, and Technology (pp. 1805-1816). Hershey, PA: IGI Global. DOI 10.4018/978-1-79983473-1.ch124

Koltay, T. (2021). Taming" information overload. Academia Letters. DOI 10.20935/AL272

Márta A.(2004). A kivonat mint önálló műfaj. Modern Filológiai Közllemények, 6, 2, 37-56.

Net1: Kudos. Letöltés: 2021.06.10. Web: https://info.growkudos.com/research -stories-communication-impact

Orasan, C. (2019). Automatic summarisation: 25 years on. Natural Language Engineering, 25, 6, 735-751. DOI 10.1017/S1351324919000524

Pinto, M. (1995). Documentary abstracting: toward a methodological model. Journal of the American Society for Information Science, 46, 3, 225-234. DOI 10.1002/(SICI)10974571(199504)46:3\%3C225::AIDASI6\%3E3.0.CO;2-N

Pinto, M, Fernández-Ramos, A. és Doucet. A-V. (2008a). Measuring Students' Information Literacy Skills through Abstracting: Case Study from 
a Library, and Information Science

Perspective, College and Research

Libraries. DOI 10.5860/crl.69.2.132

Pinto, M, Fernández-Ramos, A. és

Doucet, A-V. (2008b)The role of

information competencies and skills in

learning to abstract. Journal of

Information Science, 20, 10, 1-17. DOI

10.1177/0165551507088308

Pittman, G. és Pratta, S. (2021). Using

graphical abstracts to enrich and

expand the reach of your research.
Elsevier Connect. Letöltés: 2021.06.10.

Web:

https://www.elsevier.com/connect/u sing-graphical-abstracts-to-enrich-andexpand-the-reach-of-your-research

Reupert, A. (2017). Promoting research through video abstracts. Advances in Mental Health, 15, 1, 1-3, DOI 10.1080/18387357.2017.1312761 